\title{
Effect of aluminum fluoride complexation on fluoride removal by coagulation
}

\author{
Wen-Xin Gong ${ }^{\mathrm{a}, \mathrm{b}}$, Jiu-Hui Qu ${ }^{\mathrm{a}, *}$, Rui-Ping Liu ${ }^{\mathrm{a}}$, Hua-Chun Lan ${ }^{\mathrm{a}}$ \\ a State Key Laboratory of Environmental Aquatic Chemistry, Research Center for Eco-Environmental Sciences, Chinese Academy of Sciences, Beijing 100085, China \\ ${ }^{\mathrm{b}}$ Graduate School of Chinese Academy of Sciences, Beijing 100039, China
}

\section{A R T I C L E I N F O}

\section{Article history}

Received 10 September 2011

Received in revised form 1 December 2011

Accepted 7 December 2011

Available online 16 December 2011

\section{Keywords:}

Fluoride

Coagulation

Aluminum

Complexation

Adsorption

Coprecipitation

\begin{abstract}
A B S T R A C T
Effect of aluminum fluoride complexation on fluoride removal by Al salts coagulation was investigated by a series of batch experiments. Transformation of fluoride species in coagulation was studied by simultaneous determination of free fluoride and total fluoride at different $\mathrm{pH}$ and fluoride concentrations. Results showed that aluminum fluoride complexes dominated at low $\mathrm{pH}$ and high fluoride concentrations but more complexes did not represent higher fluoride removal. Comparison between coagulation with complexation and adsorption by $\mathrm{Al}(\mathrm{OH})_{3}$ flocs was conducted and coagulation showed higher fluoride removal efficiency than adsorption in the $\mathrm{pH}$ range of 6.0-9.0. Titration test showed that $\mathrm{Al}-\mathrm{F}$ complexes were coprecipitated with less $\mathrm{OH}^{-}$than $\mathrm{Al}^{3+}$. Characterization of FTIR and XPS also indicated that flocs after complexation was different from $\mathrm{Al}(\mathrm{OH})_{3}$ flocs with or without fluoride. It was concluded that a new $\mathrm{Al}-\mathrm{F}-\mathrm{OH}$ coprecipitate formed in coagulation and fluoride was effectively removed by the coprecipitation.
\end{abstract}

(C) 2011 Elsevier B.V. All rights reserved.

\section{Introduction}

Fluoride removal receives much attention due to the dental and skeletal fluorosis caused by the excessive intake of fluoride [1]. Among the technologies of fluoride removal coagulation is a simple and effective method in the treatment of drinking water and industrial wastewater [1-3]. In coagulation $\mathrm{Al}(\mathrm{OH})_{3}$ flocs forms during the hydrolization of $\mathrm{Al}$ salt and fluoride is removed by attachment to the flocs. In this process aluminum fluoride complexation (Al-F complexation), ion exchange, electronic attraction and physical adsorption are involved [4]. But there is not a clear conclusion about the main mechanism.

Generally, high dose of $\mathrm{Al}$ salts are required to achieve promising fluoride removal and the decrease of $\mathrm{pH}$ is inevitable. And fluoride removal is strongly dependent on $\mathrm{pH}$, so $\mathrm{pH}$ adjustment is often applied in practice [2]. The variation of $\mathrm{pH}$ influences the transformation of both $\mathrm{Al}$ and fluoride species [5-7]. In previous studies about fluoride removal only total fluoride was determined and variation of free fluoride was ignored. So, fluoride speciation and role of $\mathrm{Al}-\mathrm{F}$ complexation in fluoride removal was analyzed just by theoretical calculation rather than experiments. Though change of $\mathrm{Al}$ and fluoride species can be calculated [8], fluoride removal was also not considered in these chemical calculations. In fact fluoride could

\footnotetext{
* Corresponding author. Tel.: +8610 62849151; fax: +861062923558.

E-mail address: jhqu@rcees.ac.cn (J.-H. Qu).
}

be removed in the range of 5.0-9.0 with the addition of $\mathrm{Al}$ salt. For example, when $\mathrm{pH}>8.0$, almost $100 \%$ of fluoride was free fluoride [8] but part of fluoride was removed by $\mathrm{Al}(\mathrm{OH})_{3}$ flocs. Taking into consideration the fluoride removal, the calculated concentration of fluoride at $\mathrm{pH}>8.0$ was higher than the actual value. On the other hand, in the researches about $\mathrm{Al}-\mathrm{F}$ complexation only free fluoride was determined and focused but change of total fluoride was not considered [5,6]. Consequently, it is meaningful and important to simultaneously investigate the complexation and fluoride removal in coagulation by experiments.

In coagulation and electrocoagulation processes $\mathrm{Al}$ salts and base are co-added and adsorption is an important role in fluoride removal $[4,9]$. If $\mathrm{Al}$ reacts with fluoride before $\mathrm{Al}^{3+}$ hydrolysis, the formation of aluminum fluoride complexes (Al-F complexes) occurs firstly and fluoride is removed in the subsequent coprecipitation [10]. This process is different from conventional coagulation and mechanism of fluoride removal might also be different.

This study aims to understand the variation of fluoride species and mechanism of fluoride removal in coagulation. First, free fluoride and total fluoride are simultaneously determined to investigate the transformation of fluoride species in the removal of fluoride by coagulation. And coagulation with $\mathrm{Al}-\mathrm{F}$ complexation and adsorption by $\mathrm{Al}(\mathrm{OH})_{3}$ flocs without complexation are compared. After that the role of complexation in fluoride removal is discussed with the further characterization of precipitates using FTIR and XPS. 
Table 1

The electric potential of standard samples of free fluoride at different $\mathrm{pH}$ and ionic strengths.

\begin{tabular}{|c|c|c|c|c|c|c|}
\hline \multirow[t]{2}{*}{$\mathrm{pH}$} & \multirow[t]{2}{*}{ Ionic strength } & \multicolumn{5}{|c|}{ Electric potential (mv) } \\
\hline & & Standard 1 & Standard 2 & Standard 3 & Standard 4 & Standard 5 \\
\hline \multirow{2}{*}{3.0} & $4 \mathrm{mM} \mathrm{NaCl}$ & -285 & -258 & -244 & -226 & -209 \\
\hline & $12 \mathrm{mM} \mathrm{NaCl}$ & -285 & -258 & -244 & -227 & -209 \\
\hline \multirow{2}{*}{4.0} & $4 \mathrm{mM} \mathrm{NaCl}$ & -271 & -244 & -231 & -213 & -196 \\
\hline & $12 \mathrm{mM} \mathrm{NaCl}$ & -272 & -245 & -231 & -215 & -197 \\
\hline \multirow[b]{2}{*}{5.0} & $4 \mathrm{mM} \mathrm{NaCl}$ & -271 & -244 & -230 & -213 & -196 \\
\hline & $12 \mathrm{mM} \mathrm{NaCl}$ & -271 & -244 & -231 & -214 & -196 \\
\hline \multirow{2}{*}{6.0} & $4 \mathrm{mM} \mathrm{NaCl}$ & -269 & -241 & -228 & -212 & -195 \\
\hline & $12 \mathrm{mM} \mathrm{NaCl}$ & -270 & -243 & -230 & -214 & -195 \\
\hline \multirow[b]{2}{*}{7.0} & $4 \mathrm{mM} \mathrm{NaCl}$ & -269 & -241 & -228 & -212 & -195 \\
\hline & $12 \mathrm{mM} \mathrm{NaCl}$ & -270 & -243 & -230 & -214 & -195 \\
\hline \multirow{2}{*}{8.0} & $4 \mathrm{mM} \mathrm{NaCl}$ & -268 & -242 & -229 & -212 & -195 \\
\hline & $12 \mathrm{mM} \mathrm{NaCl}$ & -269 & -243 & -231 & -214 & -195 \\
\hline \multirow{2}{*}{9.0} & $4 \mathrm{mM} \mathrm{NaCl}$ & -268 & -242 & -228 & -211 & -194 \\
\hline & $12 \mathrm{mM} \mathrm{NaCl}$ & -268 & -242 & -228 & -213 & -195 \\
\hline
\end{tabular}

\section{Materials and methods}

\subsection{Determination of free fluoride and total fluoride}

All the reagents in the experiments were analytical grade and deionized (DI) water was used to prepare solutions. The concentration of fluoride was determined by ion selective electrode method (PF-1, Shanghai KangYi Technology). Total fluoride concentration was measured after mixing with total ionic strength adjustment buffer (citrate buffer solution) according to the Methods of Examination of Water and Wastewater [11]. The concentration of free fluoride was also determined by ion selective electrode method $[12,13]$. Free fluoride was in situ measured but no buffer was added and no dilution was conducted. Standard samples of free fluoride at different $\mathrm{pH}$ and ionic strengths were prepared. The range of $\mathrm{pH}$ was $4.0-9.0$ and $\mathrm{pH}$ was adjusted using $0.1 / 1 \mathrm{M} \mathrm{HCl}$ or $\mathrm{NaOH}$ (Orion Model 720, Thermo Electron Corp., USA). The ionic strength was evaluated by conductivity (Hach Sension 156 , Hach, USA). The ionic strength of $4 \mathrm{mM} \mathrm{NaCl}$ was nearly the value after addition of $\mathrm{Al}$ salt (dose of $\mathrm{Al}$ was $40 \mathrm{mg} / \mathrm{L}$ ) and the ionic strength of $12 \mathrm{mM} \mathrm{NaCl}$ was nearly the value after addition of $\mathrm{Al}$ salt at high fluoride concentration (Al was $40 \mathrm{mg} / \mathrm{L}$ and fluoride was $80 \mathrm{mg} / \mathrm{L}$ ). Results of calibration of free fluoride were shown in Table 1. The electric potential of standard samples at $\mathrm{pH}$ of 4.0-9.0 showed good linear ships with the logarithmic value of fluoride concentrations (all the relative coefficients were above 0.99). Table 1 also showed that the values of standards at different ionic strengths were almost the same. The effect of ionic strength in the range of this experiment was slight. So, determination of free fluoride in coagulation was available in the $\mathrm{pH}$ range of 4.0-9.0 and at low ionic strength. Content of fluoride in complexes was the difference of total fluoride concentration and free fluoride concentration.

\subsection{Batch test of coagulation and adsorption}

The coagulation test was conducted at room temperature in Plexi glass beakers using a conventional Jar test apparatus (MY 3000-6, QianjiangMeiYu Instruments, China). A $1000 \mathrm{mg} / \mathrm{L}$ fluoride stock solution was prepared by dissolving $2.210 \mathrm{~g} \mathrm{NaF}$ in $1000 \mathrm{~mL}$ DI water. Fluoride solution was prepared by diluting the stock solution to certain concentrations with DI water. Al stock solution was prepared using $\mathrm{AlCl}_{3} \cdot 6 \mathrm{H}_{2} \mathrm{O}$. In coagulation the dose of $\mathrm{Al}$ was $40 \mathrm{mg} / \mathrm{L}$ and the initial fluoride concentration varied in the range of $5-80 \mathrm{mg} / \mathrm{L}$. A total $500 \mathrm{~mL}$ of DI water was transferred to a $1 \mathrm{~L}$ beaker. Then $\mathrm{Al}$ and fluoride stock solution was added and after 2 min of mixing at $100 \mathrm{rpm} \mathrm{pH}$ was adjusted to the desired value. In Jar test of coagulation 2 min rapid mixing at $250 \mathrm{rpm}$ was applied, followed by $20 \mathrm{~min}$ of slow stirring at $50 \mathrm{rpm}$. After settlement for 30 min the supernatants were filtered through a $0.45 \mu \mathrm{m}$ membrane and analyzed. The Al concentration was measured by ICP-OES (OPTIMA 2000DV, PerkinElmer, USA). Blank test was prepared to avoid the effect of dilution after addition of $\mathrm{Al}$ or fluoride stock solution.

The adsorption by $\mathrm{Al}(\mathrm{OH})_{3}$ flocs was performed in the same procedure in the coagulation but the order of addition of $\mathrm{Al}$ and fluoride was different. The same dose of Al stock solution was added to $500 \mathrm{~mL}$ DI water and $\mathrm{pH}$ was adjusted to 7.0. The suspension of $\mathrm{Al}(\mathrm{OH})_{3}$ flocs was stirred for $10 \mathrm{~min}$ at $100 \mathrm{rpm}$. Then fluoride stock solution was added and stirring started as in the coagulation. During the adsorption, $\mathrm{pH}$ of solution was maintained at the designed value (4.0-9.0).

Kinetics of fluoride removal of coagulation and adsorption was also studied. In coagulation $\mathrm{Al}$ and fluoride were added into $1 \mathrm{~L} \mathrm{Plexi}$ glass beakers while Al was $40 \mathrm{mg} / \mathrm{L}$ and fluoride were 5 and $15 \mathrm{mg} / \mathrm{L}$, respectively. With stirring at $100 \mathrm{rpm} \mathrm{pH}$ was adjusted to 7.0 within $1 \mathrm{~min}$ and sample was collected at the desired time and analyzed. For adsorption Al was firstly added and pH was adjusted to 7.0. After fluoride was added samples were collected and analyzed. In adsorption $\mathrm{pH}$ was maintained at 7.0 in the whole process.

\subsection{Titration of Al at different fluoride concentrations}

Mixed liquor of $\mathrm{Al}$ and fluoride solution was prepared in $1 \mathrm{~L}$ Plexi glass beakers. Dose of Al was $40 \mathrm{mg} / \mathrm{L}$ with fluoride of 0,5 , and $20 \mathrm{mg} / \mathrm{L}$, respectively. With stirring at $200 \mathrm{rpm} 1 \mathrm{M} \mathrm{NaOH}$ was added to the mixed liquor using a $100 \mu \mathrm{L}$ microsyringe. The titration was conducted at room temperature and $\mathrm{N}_{2}$ was provided in the whole test. Volume of base and $\mathrm{pH}$ were recorded and plotted.

\subsection{Characterization of FTIR and XPS}

Characterization of precipitates in coagulation and adsorption were carried out using FTIR (Nicolet 5700, Thermo Electron Corp., USA) and XPS (Axis Ultra, Kratos Analytical Ltd., UK), respectively. Three samples were prepared: $\mathrm{Al}(\mathrm{OH})_{3}$ flocs without fluoride at $\mathrm{pH}$ 7.0, and flocs in adsorption and flocs in coagulation (dose of $\mathrm{Al}$ and fluoride was 40 and $15 \mathrm{mg} / \mathrm{L}$, respectively). Suspension in coagulation and adsorption was filtered using $0.45 \mu \mathrm{m}$ membrane and the powders were collected and dried at $60^{\circ} \mathrm{C}$. After characterization results were further analyzed using PeakFit Version 4.12 . 

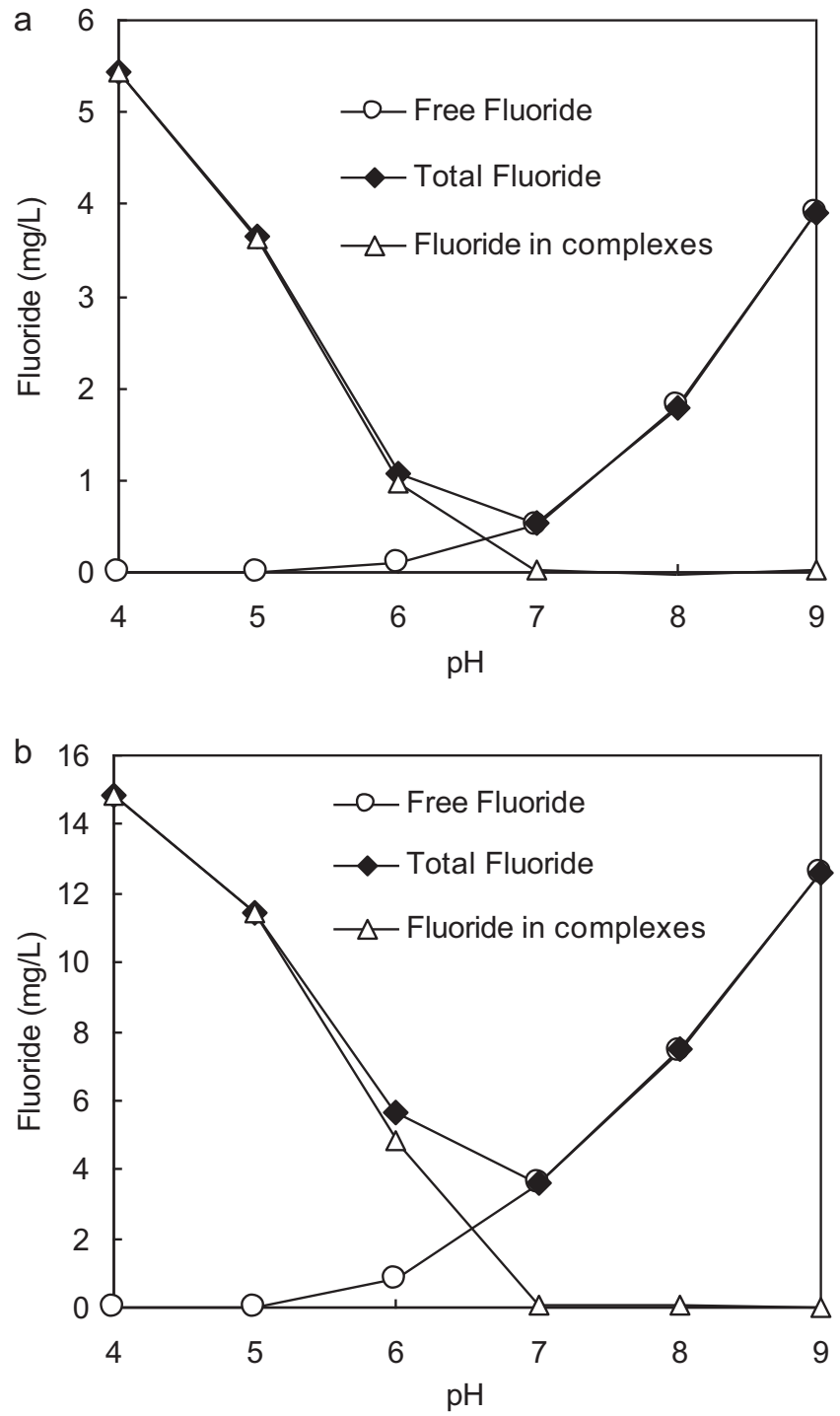

Fig. 1. Fluoride species distribution at different $\mathrm{pH}$ with fluoride of (a) $5 \mathrm{mg} / \mathrm{L}$ and (b) $15 \mathrm{mg} / \mathrm{L}$. Dose of $\mathrm{Al}=40 \mathrm{mg} / \mathrm{L}$.

\section{Results and discussion}

\subsection{Fluoride species distribution and fluoride removal at different $\mathrm{pH}$}

The fluoride species distribution and fluoride removal were studied in the $\mathrm{pH}$ range of 4.0-9.0. As shown in Fig. 1, the concentration of fluoride with different species varied with different trends. The concentration of free fluoride increased with the increase of $\mathrm{pH}$ and was equal to the concentration of total fluoride at $\mathrm{pH}>7.0$ but the content of fluoride in complex decreased in the whole $\mathrm{pH}$ range. The ratio of free fluoride to total fluoride increased from $0.2 \%$ to $98.7 \%$ as $\mathrm{pH}$ increased from 5.0 to 7.0 (Fig. 1b). At $\mathrm{pH}<5.0$, fluoride was mostly in the form of $\mathrm{Al}-\mathrm{F}$ complexes, there was little free fluoride. Due to competition of $\mathrm{OH}^{-}$, complexes were dissociated and free fluoride increased at higher $\mathrm{pH}$. The change of total fluoride in Fig. 1 reflected the removal of fluoride at different $\mathrm{pH}$. The minimum concentration of fluoride was 0.5 and $3.6 \mathrm{mg} / \mathrm{L}$ at $\mathrm{pH} 7.0$ with initial fluoride concentration of 5 and $15 \mathrm{mg} / \mathrm{L}$, respectively. For total fluoride removal the optimal $\mathrm{pH}$ was 7.0, and fluoride removal decreased at lower or higher pH. Fig. 1 also indicated that the transformation of fluoride species and fluoride removal were strongly dependent on $\mathrm{pH}$. Weak acidic conditions were beneficial to the complexation between $\mathrm{Al}$ and fluoride. As $\mathrm{pH}$ increased to 7.0 complexes were completely dissociated to free fluoride and the best removal of total fluoride was obtained.

\subsection{Formation of $A l-F$ complexes and fluoride removal at different fluoride concentrations}

Effect of fluoride concentration on $\mathrm{Al}-\mathrm{F}$ complexation and fluoride removal in coagulation was studied at $\mathrm{pH}$ 6.0, 7.0 and 8.0. As shown in Fig. 2a, the ratio of fluoride in complexes to total fluoride increased from $19.6 \%$ to $83.4 \%$ as fluoride concentration increased from $20 \mathrm{mg} / \mathrm{L}$ to $80 \mathrm{mg} / \mathrm{L}$ at $\mathrm{pH} 6.0$. At $\mathrm{pH} 7.0$ the percent of fluoride in complexes was below $0.5 \%$ while the initial fluoride concentration was lower than $40 \mathrm{mg} / \mathrm{L}$ and finally increased to $39.2 \%$ at fluoride concentration was $80 \mathrm{mg} / \mathrm{L}$. At $\mathrm{pH}$ 8.0, free fluoride was the dominant species and the percent of fluoride in complexes was below $0.1 \%$ with fluoride concentration of $5-80 \mathrm{mg} / \mathrm{L}$. At weak acidic and neutral conditions higher fluoride concentration induced more Al-F complexes. Fig. 2b illustrated the effect of initial fluoride concentration on fluoride removal. The removal of fluoride firstly increased as fluoride concentration increased and decreased after initial fluoride concentrations were above 40, 60 and $60 \mathrm{mg} / \mathrm{L}$ at $\mathrm{pH}$ 6.0, 7.0 and 8.0, respectively. Low $\mathrm{pH}$ and high fluoride concentration were advantageous for $\mathrm{Al}-\mathrm{F}$ complexation but disadvantageous for fluoride removal.

Results in Fig. 2c indicated that the dissolving of $\mathrm{Al}$ occurred at low $\mathrm{pH}$ and high fluoride concentration. The complexation increased the content of soluble $\mathrm{Al}$ and the $\mathrm{Al}-\mathrm{F}$ complexes were the main species for soluble $\mathrm{Al}$ [5]. The dissolving $\mathrm{Al}$ and fluoride were in the form of soluble Al-F complexes but still remained in the aqueous solution. From this perspective, the complexation was disadvantageous to fluoride removal at low $\mathrm{pH}$ and high fluoride concentration.

\subsection{Comparison of fluoride removal between coagulation and adsorption}

Coagulation by $\mathrm{Al}$ salt and adsorption by $\mathrm{Al}(\mathrm{OH})_{3}$ flocs are two processes with different mechanisms. In this study the removal of fluoride by coagulation and adsorption at different fluoride concentrations was compared and results were shown in Figs. 3 and 4.

As shown in Fig. 3 fluoride concentration in coagulation was lower than that in adsorption at $\mathrm{pH}$ of $6.0-9.0$. The optimal $\mathrm{pH}$ for fluoride removal in coagulation and adsorption was about 7.0 and 6.0, respectively. Fig. 4 showed the kinetic removal of fluoride in coagulation and adsorption. The removal of fluoride by coagulation was completed within $2 \mathrm{~min}$. Comparatively, fluoride removal by adsorption achieved equilibrium after $15 \mathrm{~min}$ with fluoride concentration of $5 \mathrm{mg} / \mathrm{L}$. While fluoride was $15 \mathrm{mg} / \mathrm{L}$, more than $60 \mathrm{~min}$ was needed to reach the equilibrium. The process of coagulation involved $\mathrm{Al}-\mathrm{F}$ complexation, Al hydrolysis and precipitation. All the reactions were strongly dependent on $\mathrm{pH}$ and were quick processes with time scale of $10^{2} \mathrm{~s}[12,14]$. During the adsorption process, fluoride was removed by ion exchange with $\mathrm{OH}^{-}[8,11]$. The acidic condition favored the release of $\mathrm{OH}^{-}$and fluoride removal. This slow reaction of ion exchange also required more time to achieve equilibrium. As seen in Figs. 3 and 4, the coagulation showed higher removal efficiency and faster removal than adsorption. It was implied that $\mathrm{Al}-\mathrm{F}$ complexation promoted fluoride removal in coagulation. 

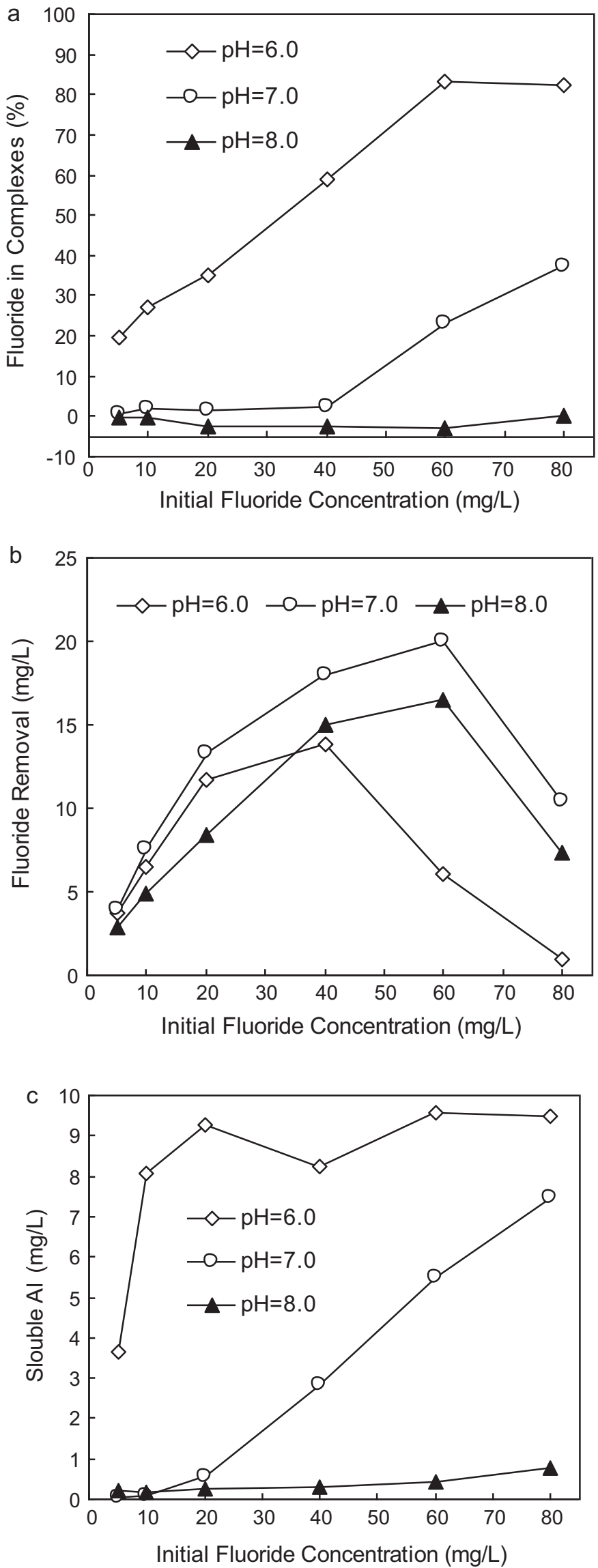

Fig. 2. Effect of initial fluoride concentration on (a) Al-F complexation, (b) fluoride removal and (c) dissolving of aluminum. Dose of $\mathrm{Al}=40 \mathrm{mg} / \mathrm{L}$, and initial fluoride concentration $=5-80 \mathrm{mg} / \mathrm{L}$.

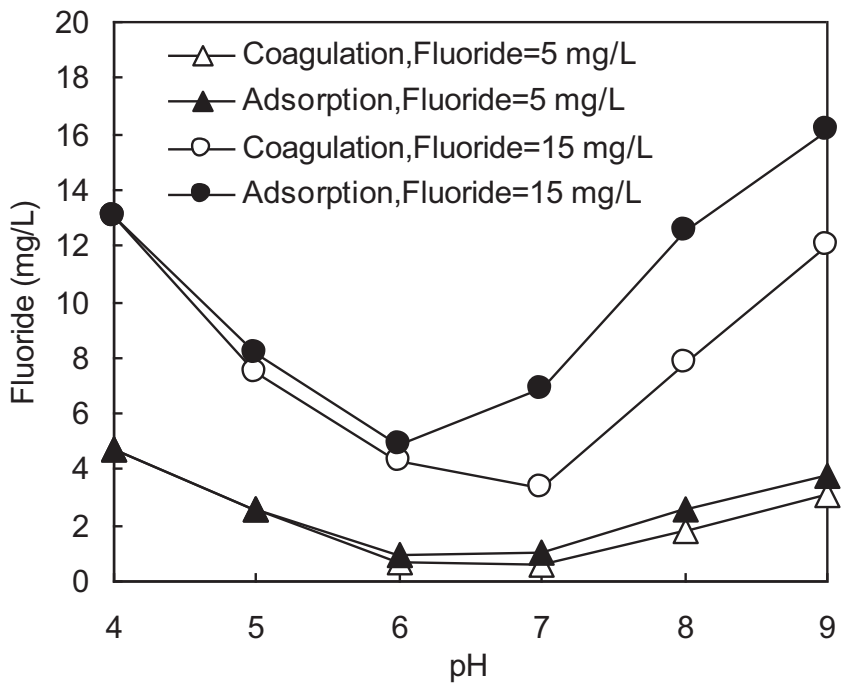

Fig. 3. Comparison of fluoride removal between coagulation and adsorption at different $\mathrm{pH}$. Dose of $\mathrm{Al}=40 \mathrm{mg} / \mathrm{L}$.
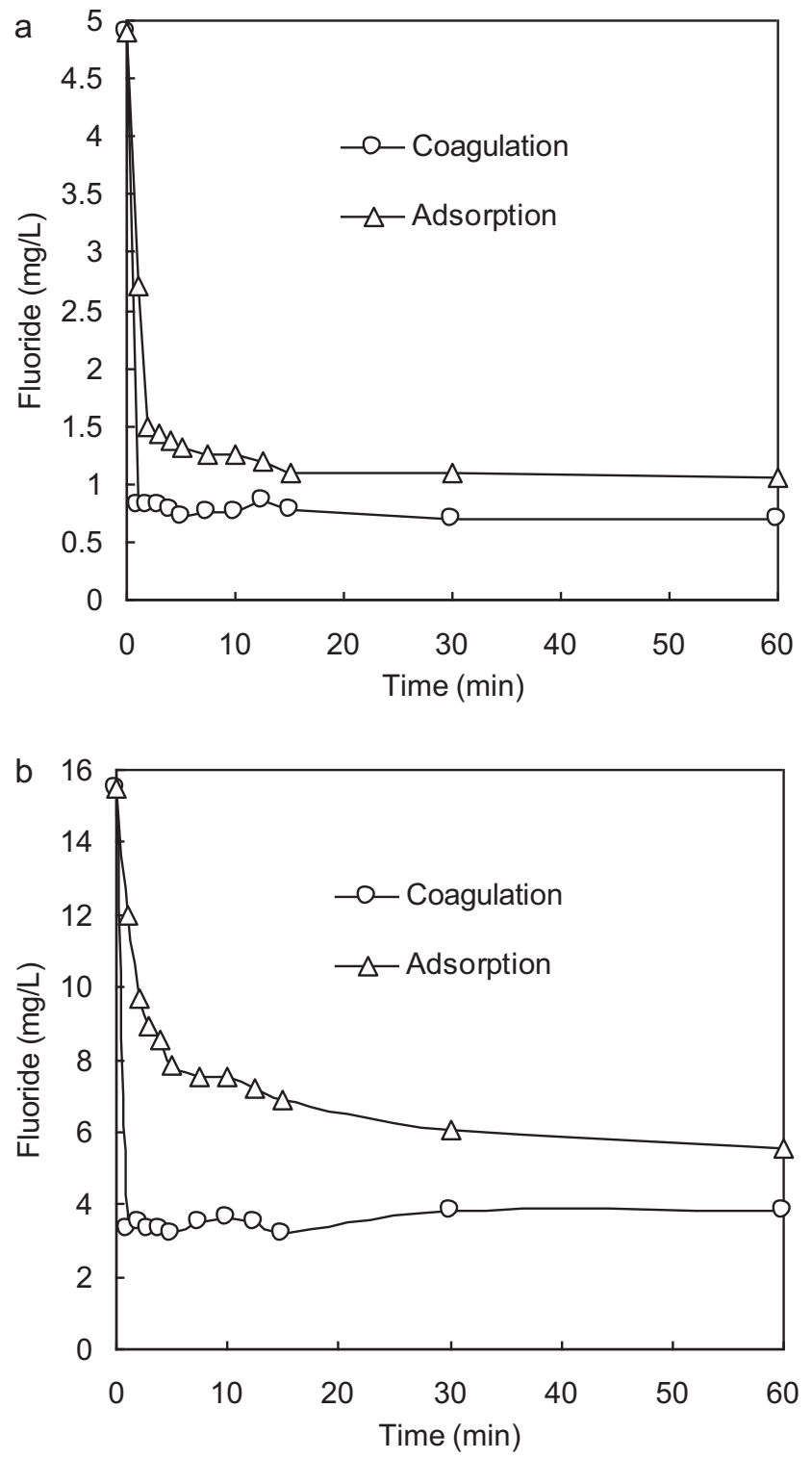

Fig. 4. Kinetic removal of fluoride by coagulation and adsorption at (a) fluoride $=5 \mathrm{mg} / \mathrm{L}$ and $(\mathrm{b}$ ) fluoride $=15 \mathrm{mg} / \mathrm{L}$. Dose of $\mathrm{Al}=40 \mathrm{mg} / \mathrm{L}$ and $\mathrm{pH}$ 7.0. 


\subsection{Al hydrolysis with Al-F complexation}

Role of complexation in coagulation was further studied by titration method. Fig. 5 illustrated the variation of $\mathrm{pH}$ during the addition of $\mathrm{NaOH}$ into $\mathrm{AlCl}_{3}$ solution at fluoride concentrations of 0,5 , and $20 \mathrm{mg} / \mathrm{L}$, respectively. The $\mathrm{pH}$ increased with the addition of $\mathrm{NaOH}$ and the ' $\mathrm{S}$ ' shape curves were observed. At $\mathrm{pH}$ of about 7.0 the volume of $\mathrm{NaOH}$ were $1880,1800,1580 \mu \mathrm{L}$ at fluoride concentrations of 0,5 , and $20 \mathrm{mg} / \mathrm{L}$, respectively. The volume of $\mathrm{NaOH}$ decreased at higher fluoride concentration and the correspondence between dosage of base and fluoride concentration was ascribed to the effect of formed Al-F complexes. When $\mathrm{pH}$ increased to 9.0, the total volumes of $\mathrm{NaOH}$ at different fluoride concentration increased to the same value. Due to the strong competition of $\mathrm{OH}^{-}$with fluoride the effect of complexation was subtle at higher $\mathrm{pH}$.

Titration of $\mathrm{Al}$ with different concentration of fluoride was the reaction of $\mathrm{OH}^{-}$and $\mathrm{Al}$ ions or $\mathrm{Al}-\mathrm{F}$ complexes. Considering the transformation of fluoride species and fluoride removal at different $\mathrm{pH}$ (Fig. 1), titration could reflect the changes of complexes, $\mathrm{Al}$ ions and $\mathrm{OH}^{-}$in fluoride removal. The $\mathrm{Al}-\mathrm{F}$ complexes were dominant at acidic conditions before titration. $\mathrm{As}^{-} \mathrm{H}^{-}$was added, $\mathrm{Al}-\mathrm{F}$ complexes were partly dissociated to $\mathrm{Al}^{3+}$, free fluoride and other species, such as $\mathrm{Al}(\mathrm{OH})^{2+}$ and $\operatorname{AlF}(\mathrm{OH})^{+}[5,15]$. In aqueous solution the soluble species mainly included $\mathrm{Al}-\mathrm{F}$ complexes, $\mathrm{Al}-\mathrm{OH}$ complexes, $\mathrm{Al}^{3+}$ and free fluoride. Fig. 2c showed that little $\mathrm{Al}^{3+}$ was dissolved with fluoride concentration below $20 \mathrm{mg} / \mathrm{L}$ at pH 7.0. With addition of base most of $\mathrm{Al}$ species were precipitated at neutral $\mathrm{pH}$. Decrease of volume of $\mathrm{NaOH}$ after complexation implied that complexes could be directly precipitated. So, it was predicted that $\mathrm{Al}-\mathrm{F}$ complexes reacted with less $\mathrm{OH}^{-}$and a new precipitate of $\mathrm{Al}-\mathrm{F}-\mathrm{OH}$ was formed. The main reactions were expressed as Eqs. (1)-(4):

$\mathrm{Al}^{3+}+3 \mathrm{OH}^{-} \rightarrow \mathrm{Al}(\mathrm{OH})_{3}$

$\mathrm{AlF}^{2+}+\mathrm{OH}^{-} \rightarrow \mathrm{AlF}_{2}(\mathrm{OH})$

$\mathrm{AlF}(\mathrm{OH})^{+}+\mathrm{OH}^{-} \rightarrow \operatorname{AlF}(\mathrm{OH})_{2}$

$\mathrm{AlF}_{2}{ }^{+}+2 \mathrm{OH} \rightarrow \mathrm{AlF}(\mathrm{OH})_{2}$

Compared with $\mathrm{Al}^{3+}$, the $\mathrm{Al}-\mathrm{F}$ complexes could react with less $\mathrm{OH}^{-}$and then act as the precursor or nucleus of coprecipitate. While the complexes and free fluoride were coprecipitated or incorporated in coprecipitate the removal of fluoride was achieved. As base was further added, competition between $\mathrm{OH}^{-}$and fluoride occurred at $\mathrm{pH}$ above 7.0 and the process of coprecipitation was

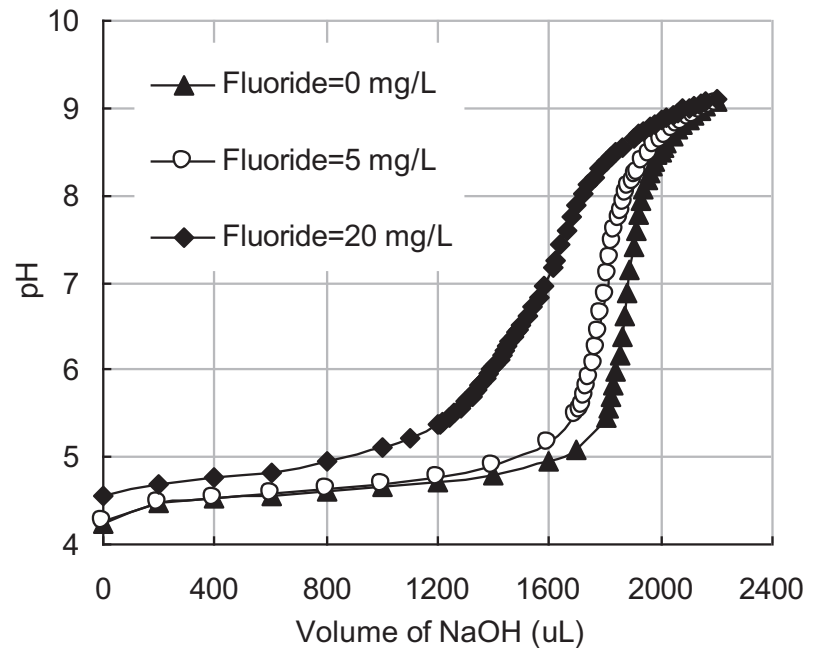

Fig. 5. Titration curve of $\mathrm{Al}$ by $\mathrm{NaOH}$ with different fluoride concentrations. Dose of $\mathrm{Al}=40 \mathrm{mg} / \mathrm{L}$ and $\mathrm{NaOH}=1 \mathrm{M}$.

Table 2

XPS binding energies of different samples in coagulation and adsorption.

\begin{tabular}{llll}
\hline & \multicolumn{3}{l}{ Binding energy $(\mathrm{eV})$} \\
\cline { 2 - 4 } & $\mathrm{Al} \mathrm{2p}$ & $\mathrm{O} \mathrm{1s}$ & $\mathrm{F} \mathrm{1s}$ \\
\hline $\mathrm{Al}(\mathrm{OH})_{3}$ flocs & 74.27 & 532.02 & \\
Flocs of adsorption & 74.57 & 532.12 & 685.12 \\
Flocs of coagulation & 74.81 & 532.36 & 685.22 \\
$\mathrm{AlF}_{3} \cdot 3 \mathrm{H}_{2} \mathrm{O}$ & 76.28 & & 686.33 \\
$\mathrm{Na}_{3} \mathrm{AlF}_{6}$ & 75.31 & & 685.19 \\
\hline
\end{tabular}

negatively affected. This corresponded to the decrease of fluoride removal at high $\mathrm{pH}$ as shown in Figs. 1 and 3.

\subsection{Characterization of FTIR and XPS of flocs}

FTIR spectroscopy was useful for investigating characteristics of amorphous oxides and flocs. The FTIR spectra of precipitates in coagulation and adsorption were given in Fig. 6 . The peaks in the $400-1500 \mathrm{~cm}^{-1}$ region corresponded to the stretching and bending modes of $\mathrm{Al}-\mathrm{O}$ [16]. Peaks of flocs in coagulation at 590 and $995 \mathrm{~cm}^{-1}$ shrinked and shifted compared with that of $\mathrm{Al}(\mathrm{OH})_{3}$ flocs in adsorption. Results of peak fitting showed that some peaks of $\mathrm{Al}-\mathrm{O}$ bond ( 727 and $1207 \mathrm{~cm}^{-1}$ ) disappeared in flocs of

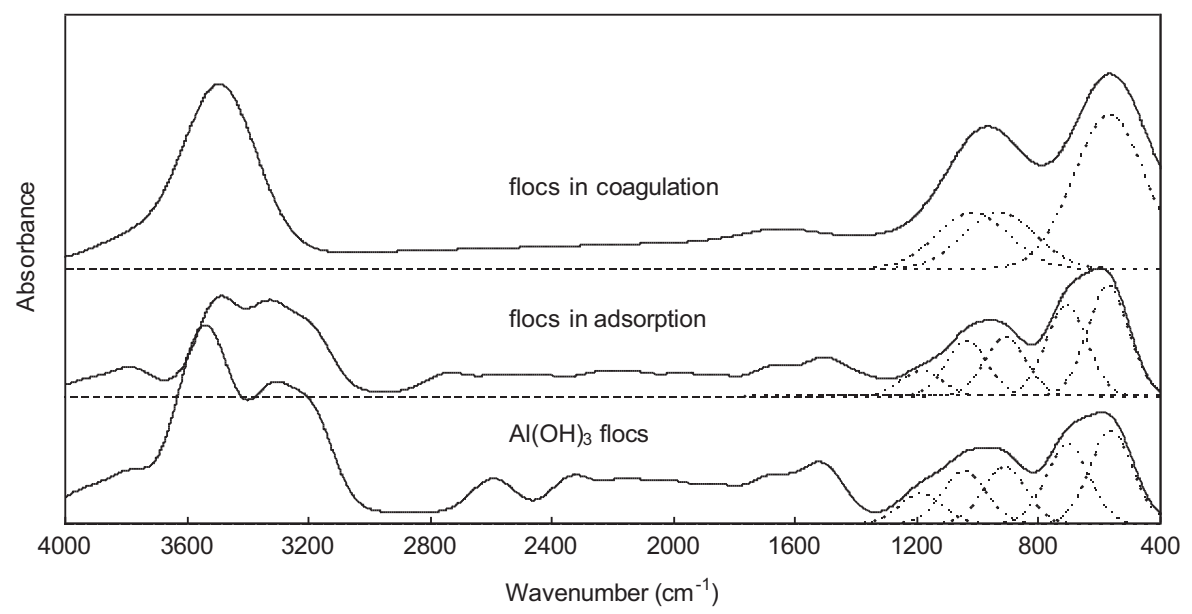

Fig. 6. FTIR of flocs in coagulation and adsorption. Dashed lines are the results after peak fitting. 
coagulation. The differences between coprecipitates in coagulation and $\mathrm{Al}(\mathrm{OH})_{3}$ flocs indicated that bands of $\mathrm{Al}-\mathrm{O}$ were affected by fluoride [17]. This indicated the involvement of $\mathrm{Al}-\mathrm{F}$ complexation in coagulation. The FTIR spectra of flocs before and after adsorption were almost the same. In adsorption fluoride was removed by ion exchange of fluoride with $\mathrm{OH}^{-}$on the surface of $\mathrm{Al}(\mathrm{OH})_{3}$, so main chemical structure of $\mathrm{Al}(\mathrm{OH})_{3}$ remained as before.

The precipitates were further characterized by XPS and results were shown in Table 2 . The $\mathrm{O} 1 \mathrm{~s}$ binding energy $(532.36 \mathrm{eV})$ and $\mathrm{Al} 2 \mathrm{p}$ binding energy $(74.81 \mathrm{eV})$ of flocs in coagulation were much higher than that of $\mathrm{Al}(\mathrm{OH})_{3}$ flocs with or without fluoride. The higher binding energy was attributed to the transfer or share of electron between $\mathrm{Al}$ or $\mathrm{O}$ and fluoride and indicated the strong bonding of $\mathrm{Al}-\mathrm{F}$ in coagulation. The difference of binding energy showed that the flocs in coagulation with $\mathrm{Al}-\mathrm{F}$ complexation was not $\mathrm{Al}(\mathrm{OH})_{3}$ flocs. The differences of the $\mathrm{Al} 2 \mathrm{p}$ binding energy between flocs and solids of $\mathrm{AlF}_{3}$ and $\mathrm{Na}_{3} \mathrm{AlF}_{6}$ showed that the flocs were not in the form of $\mathrm{AlF}_{3}$ or $\mathrm{Na}_{3} \mathrm{AlF}_{6}$. The binding energy of $\mathrm{F}$ $1 \mathrm{~s}$ of flocs in coagulation $(685.22 \mathrm{eV})$ was close to that of $\mathrm{Na}_{3} \mathrm{AlF}_{6}$ $(685.19 \mathrm{eV})$. It was indicated that fluoride was incorporated in the flocs with the bonding of Al-F [5]. From characterization of FTIR and XPS it could be concluded that a new coprecipitate of $\mathrm{Al}-\mathrm{F}-\mathrm{OH}$ formed in coagulation with $\mathrm{Al}-\mathrm{F}$ complexation. Complexation in coagulation also induced strong bonding between $\mathrm{Al}$ and fluoride in the formed coprecipitate. As a result effective fluoride removal was achieved in coagulation after Al-F complexation.

\section{Conclusions}

The Al-F complexation and fluoride removal in coagulation was quantified at different $\mathrm{pH}$ and fluoride concentrations. The concentration of free fluoride decreased with $\mathrm{pH}$ and the optimal $\mathrm{pH}$ for removal of total fluoride was about 7.0. Low $\mathrm{pH}$ and high fluoride concentration favored for $\mathrm{Al}-\mathrm{F}$ complexation but showed negative effect on fluoride removal. Comparatively, coagulation with complexation showed higher removal efficiency toward fluoride than $\mathrm{Al}(\mathrm{OH})_{3}$ adsorption, and this indicated the promotion of Al-F complexation on fluoride removal. The effect of $\mathrm{Al}-\mathrm{F}$ complexation on $\mathrm{Al}$ hydrolysis was proved by the titration test. $\mathrm{Al}-\mathrm{F}$ complexes reacted with less $\mathrm{OH}^{-}$with comparison to $\mathrm{Al}^{3+}$ and were directly precipitated at neutral $\mathrm{pH}$. Characterization of FTIR and XPS also showed that precipitate after complexation was different from $\mathrm{Al}(\mathrm{OH})_{3}$ flocs with or without fluoride. It was concluded that
$\mathrm{Al}-\mathrm{F}-\mathrm{OH}$ coprecipitate formed with $\mathrm{Al}-\mathrm{F}$ complexes as precursor in coagulation and the coprecipitation with complexation benefited the removal of fluoride by coagulation.

\section{Acknowledgments}

This work was supported by the Funds for Creative Research Groups of China (Grant no. 50621804) and the National Natural Science Foundation of China (Grant no. 21177143).

\section{References}

[1] M.D.G. de Luna, Warmadewanthi, J.C. Liu, Combined treatment of polishing wastewater and fluoride-containing wastewater from a semiconductor manufacturer, Colloids Surf. A: Physicochem. Eng. Aspects 347 (2009) 64-68.

[2] J. Fawell, K. Bailey, J. Chilton, E. Dahi, L. Fewtrell, Y. Magara, Fluoride in DrinkingWater, IWA Publishing, London, 2006, pp. 62-72.

[3] M. Mohapatra, S. Anand, B.K. Mishra, D.E. Giles, P. Singh, Review of fluoride removal from drinking water, J. Environ. Manage. 91 (2009) 67-77.

[4] J.H. Lu, W.P. Liu, W. Zheng, The removal mechanisms of fluoride ion by Al salt coagulant, Acta Scientiae Circumstantiae 20 (2000) 709-713.

[5] B.J. Plankey, H.H. Patterson, Kinetics of Al fluoride complexation in acidic waters, Environ. Sci. Technol. 20 (1988) 160-165.

[6] M.S. Corbillon, M.A. Olazabal, J.M. Madariaga, Potentiometric study of aluminium-fluoride complexation equilibria and definition of the thermodynamic model, J. Solution Chem. 37 (2008) 567-579.

[7] H.J. Liu, C.Z. Hu, H. Zhao, J.H. Qu, Coagulation of humic acid by $\mathrm{PACl}$ with high content of $\mathrm{Al}_{13}$ : the role of Al speciation, Sep. Purif. Technol. 70 (2009) 225-230.

[8] Y. Ku, H.M. Chiou, The adsorption of fluoride ion from aqueous solution by activated alumina, Water Air Soil Pollut. 133 (2002) 349-360.

[9] F. Shen, X. Chen, P. Gao, G. Chen, Electrochemical removal of fluoride ions from industrial wastewater, Chem. Eng. Sci. 58 (2003) 987.

[10] C.Y. Hu, S.L. Lo, W.H. Kuan, Effects of the molar ratio of hydroxide and fluoride to $\mathrm{Al}(\mathrm{III})$ on fluoride removal by coagulation and electrocoagulation, J. Colloid Interface Sci. 283 (2005) 472-476.

[11] S.X. Teng, S.G. Wang, W.X. Gong, X.W. Liu, B.Y. Gao, Removal of fluoride by hydrous manganese oxide-coated alumina: performance and mechanism, J. Hazard Mater. 168 (2009) 1004-1011.

[12] G.S. Townsend, B.W. Bache, Kinetics of aluminium fluoride complexation in single- and mixed-ligand systems, Talanta 39 (1992) 1531-1535.

[13] J.F. Liebman, M. Ponikvar, Ion selective electrode determination of free versus total fluoride ion in simple and fluoroligand coordinated hexafluoropnictate (PnF6- ${ }^{-}$Pn = P, As, Sb, Bi) salts, Struct. Chem. 16 (2005) 521-528.

[14] M.M. Clark, R.M. Srlvastava, Mixing and aluminum precipitation, Environ. Sci. Technol. 27 (1993) 2181-2189.

[15] N. Radic, M. Bralic, Aluminium fluoride complexation and its ecological importance in the aquatic environment, Sci. Total Environ. 172 (1995) 237-243.

[16] K. Biswas, S.K. Saha, U.C. Ghosh, Adsorption of fluoride from aqueous solution by a synthetic iron(III)-Al(III) mixed oxide, Ind. Eng. Chem. Res. 46 (2007) 5346-5356.

[17] M.G. Sujana, S. Anand, Iron and aluminium based mixed hydroxides: a novel sorbent for fluoride removal from aqueous solutions, Appl. Surf. Sci. 256 (2010) 6956-6962. 